\title{
Regulation of pituitary thyrotropin gene expression during Xenopus metamorphosis: negative feedback is functional throughout metamorphosis
}

\author{
Richard G Manzon and Robert J Denver \\ Department of Molecular, Cellular and Developmental Biology, University of Michigan, Ann Arbor, Michigan 48109, USA \\ (Requests for offprints should be addressed to Richard Manzon, Department of Biology, University of Regina, 3737 Wascana Parkway, Regina SK S4S-0A2, \\ Canada; Email: richard.manzon@uregina.ca)
}

\begin{abstract}
Several hypotheses have been proposed to explain the increase and sustained expression of pituitary thyrotropin (TSH) in the presence of elevated plasma thyroid hormone $(\mathrm{TH})$ concentrations at metamorphic climax in amphibians. It has been proposed that the negative feedback of TH on TSH is inoperative until metamorphic climax, and that it is established at this time by the upregulation of pituitary deiodinase type II (DII); DII converts thyroxine $\left(\mathrm{T}_{4}\right)$ to $3,5,3^{\prime}$-triiodothyronine $\left(\mathrm{T}_{3}\right)$. However, earlier investigators, using indirect measures of TSH, reported that TH negative feedback on TSH was functional in premetamorphic tadpoles. In an effort to understand pituitary TSH regulation during amphibian metamorphosis, we analyzed multiple pituitary genes known or hypothesized to be involved in TSH regulation in tadpoles of Xenopus laevis. Tadpole pituitary explant cultures were used to examine direct negative feedback on TSH mRNA expression. Negative feedback is operative
\end{abstract}

in the early prometamorphic tadpole pituitary and both $\mathrm{T}_{3}$ and $\mathrm{T}_{4}$ can downregulate TSH mRNA expression throughout metamorphosis. The expression of both DII and $\mathrm{TH}$ receptor $\beta \mathrm{A}$ mRNAs increased during development and peaked at climax; however, these increases coincided with similar increases in deiodinase type III, which inactivates TH. Moreover, corticotropin-releasing factor (CRF) receptors, CRF binding protein and thyrotropin-releasing hormone receptor type 2 mRNA expression also peaked at climax. Our data suggest that the regulation of TSH is more complex than the timing of DII expression, and likely involves a balance between stimulation of TSH synthesis and secretion by neuropeptides (e.g. CRF) of hypothalamic or pituitary origin, increased pituitary sensitivity to neuropeptides through upregulation of their receptors, and intrapituitary TH levels.

Journal of Endocrinology (2004) 182, 273-285

\section{Introduction}

Thyroid hormone $(\mathrm{TH})$ is known to be the primary hormonal stimulus for amphibian metamorphosis (see Kikuyama et al. 1993, Shi 2000). However, the neuroendocrine mechanisms responsible for the obligatory rise in $\mathrm{TH}$ production during metamorphosis are still poorly understood. It is well established that the hypothalamus and pituitary gland regulate tadpole thyroid activity, but the precise molecular controls of the hypothalamicpituitary-thyroid axis remain to be elucidated. Earlier studies showed that hypophysectomy prior to late prometamorphosis resulted in metamorphic stasis (Dodd \& Dodd 1976) and abolished ${ }^{131} \mathrm{I}$ uptake by the thyroid gland. These effects could be reversed by treatment with tadpole pituitary extract or mammalian thyrotropin (TSH; Dodd \& Dodd 1976). Furthermore, passive immunization of Rana catesbeiana tadpoles with an antiserum to bovine TSH prevented spontaneous metamorphosis (Eddy \&
Lipner 1976). A biologically active TSH was purified from bullfrog pituitaries by MacKenzie and Licht (1978) but, to date, no amphibian TSH has been characterized biochemically. However, cDNAs for TSH $\beta$ and the $\alpha$-glycoprotein subunit $(\alpha$-GSU) have been isolated from Xenopus laevis (Buckbinder \& Brown 1993) and R. catesbeiana (Okada et al. 2000). In both X. laevis and $R$. catesbeiana, pituitary TSH mRNA expression increases during prometamorphosis in parallel with increasing plasma TH concentrations, which supports earlier findings of an increase in pituitary TSH bioactivity during metamorphosis (Dodd \& Dodd 1976, Kikuyama et al. 1993).

Negative feedback by TH on pituitary TSH biosynthesis and secretion is a universal phenomenon among vertebrates (Licht \& Denver 1990, Cohen et al. 2000). Direct negative feedback by TH on pituitary TSH secretion was demonstrated using in vitro bioassays in adults of two frog species ( $R$. pipiens: $\mathrm{S}$ Pavgi, personal communication; R. ridibunda: Jacobs \& Kuhn 1992) but similar studies have 
not been conducted in tadpoles. If negative feedback is operative in tadpoles it is puzzling that they are able to mount a sustained rise in TSH production in the face of greatly elevated circulating TH concentrations (Leloup \& Buscaglia 1977, White \& Nicoll 1981). Either negative feedback is not functional during pre- and prometamorphosis, or there is a strong hypothalamic drive for TSH production that overcomes the negative feedback exerted by the elevated plasma $\mathrm{TH}$ concentrations. Etkin and colleagues (Etkin et al. 1965, Etkin 1966, 1968) hypothesized that $\mathrm{TH}$ exerts a maturational effect on the hypothalamus, median eminence and pituitary gland, and this form of positive feedback is responsible for the sustained rise in plasma $\mathrm{TH}$ concentrations that drive metamorphosis. Etkin (1968) also proposed that negative feedback on pituitary TSH does not develop until metamorphic climax. More recently, Huang and colleagues (2001) proposed that negative feedback on pituitary TSH in X. laevis develops only at metamorphic climax, coincident with the onset of deiodinase type II (DII) expression. However, they did not directly test whether feedback was in fact absent before climax, and a considerable body of data suggests that negative feedback on pituitary TSH is functional in the premetamorphic tadpole. Kaye (1961) provided evidence that negative feedback can operate from a very early stage of development; i.e. tadpoles of $R$. pipiens treated with TH at Taylor Kollros stage III exhibited depressed thyroidal ${ }^{131}$ I uptake. Others showed that treatment of premetamorphic tadpoles with goitrogens induced enlargement of the thyroid and degranulation of pituitary thyrotropes (Goos et al. 1968a,b, see also Dodd \& Dodd 1976). Conversely, replacement with thyroxine $\left(\mathrm{T}_{4}\right)$ reversed the effects of goitrogen treatment on the thyrotropes, suggesting that negative feedback on TSH was operative in the premetamorphic tadpole (Goos et al. 1968b, Kurabuchi et al. 1992). Buckbinder and Brown (1993) reported an elevation in TSH $\beta$ mRNA in the pituitary of a premetamorphic tadpole treated with the goitrogen, methimazole.

In the present study we used pituitary explant cultures derived from $X$. laevis tadpoles at different developmental stages to determine whether and when $\mathrm{TH}$ is capable of exerting negative feedback on TSH gene expression. Our data show that $\mathrm{TH}$ can act directly on the tadpole pituitary from early prometamorphosis through metamorphic climax to downregulate TSH gene expression; i.e. negative feedback does not abruptly form at metamorphic climax as suggested by Huang and colleagues (2001). Our expression analyses of pituitary genes that are known or suspected to be involved in TSH regulation support Etkin's maturational hypothesis, whereby the hypothalamicpituitary unit develops in response to rising plasma TH titers. Moreover, our data suggest that the pituitary gland expresses the genes necessary for autostimulation of TSH synthesis and secretion (i.e. corticotropin-releasing factor (CRF) and thyrotropin-releasing hormone (TRH)) perhaps via an autocrine or paracrine mechanism.

\section{Materials and Methods}

\section{Animal husbandry}

$X$. laevis tadpoles were obtained by in-house breeding or were purchased from Xenopus I (Dexter, MI, USA). Tadpoles were raised in dechlorinated tap water $\left(20-22^{\circ} \mathrm{C}\right)$ under $12 \mathrm{~h}$ light:12 h darkness conditions and were fed Frog Brittle (Nasco, Fort Atkinson, WI, USA) which was available ad libitum. Developmental stages were assigned according to the method of Nieuwkoop and Faber (1956) (NF stage). All procedures involving animals were conducted in accordance with the guidelines of the University Committee on the Care and Use of Animals of the University of Michigan.

\section{Pituitary explant culture}

Pituitary explant methods were based on those described by Denver (1988) with modifications. X. laevis tadpoles were reared in aquarium water containing oxytetracycline $(10 \mathrm{mg} / \mathrm{l})$ for $16-20 \mathrm{~h}$ before being killed. For tissue harvest, tadpoles were anesthetized by immersion in $0.01 \%$ benzocaine (Sigma, St. Louis, MO, USA), pituitaries were removed and placed two per well in 24-well tissue culture dishes containing $1 \mathrm{ml}$ ice cold amphibian strength Dulbecco's modified Eagle's medium (DMEM; diluted to 0.66 mammalian strength to account for the lower osmotic pressure of amphibian body fluids). The DMEM contained $10 \mathrm{mM}$ HEPES, $3 \mathrm{mM} \mathrm{NaHCO}, 0 \cdot 1 \%$ bovine serum albumin, $0 \cdot 01 \%$ bacitracin, $0 \cdot 005 \%$ Tween 80 , and antibiotic-antimycotic (Invitrogen, Carlsbad, CA, USA). Each tissue culture well contained two pituitaries to ensure sufficient tissue for analysis.

Tissue culture was conducted with shaking, in a dark, humidified chamber under an atmosphere of $95 \% \mathrm{O}_{2}$ and $5 \% \mathrm{CO}_{2}$. Tissues were cultured for $20 \mathrm{~h}$ prior to the initiation of hormone treatments to allow for stabilization of TSH synthesis and secretion (see Denver 1988). Following this $20 \mathrm{~h}$ pre-incubation period, $250 \mu \mathrm{l}$ DMEM containing an appropriate concentration of $\mathrm{TH}$ was added to the wells. Control groups received $250 \mu \mathrm{l}$ DMEM without TH. Pituitaries were incubated for an additional $24 \mathrm{~h}$ before harvest and RNA extraction. Dose sensitivity of TH negative feedback on TSH gene expression was tested at three different developmental stages: early prometamorphosis (NF stage 56), mid-prometamorphosis (NF stage 59) and metamorphic climax (NF stage 62). Pituitaries were cultured with different doses (final concentration of $0,1,10$, or $100 \mathrm{nM})$ of $3,5,3^{\prime}-$ triiodothyronine $\left(\mathrm{T}_{3}\right)$ (Sigma) or thyroxine $\left(\mathrm{T}_{4}\right)$ (Sigma) in separate experiments. Each hormone treatment at each of the developmental stages was carried out in triplicate. At the termination of each explant experiment pituitaries were immediately extracted for RNA and stored at $-80{ }^{\circ} \mathrm{C}$ for analysis by Northern blotting. 
RNA extraction and analysis

Tissues were collected into $800 \mu \mathrm{l}$ Trizol reagent (Invitrogen). Glycogen (20 $\mathrm{g}$; Invitrogen) was added and RNA was extracted according to the manufacturer's protocol. The RNAs were stored in RNase-free water at $-80{ }^{\circ} \mathrm{C}$ prior to analysis by either Northern blotting or reverse-transcription polymerase chain reaction (RT-PCR).

\section{Northern blotting}

Northern blots were prepared following methods described previously (Denver et al. 1997). All probes were labeled with $\left[{ }^{32} \mathrm{P}\right] \mathrm{dCTP}$ by random priming (Amersham Biosciences, Piscataway, NJ, USA). Blots were initially probed with a $X$. laevis TSH $\beta$ cDNA (Buckbinder \& Brown 1993) then stripped and reprobed with a $X$. laevis a-GSU cDNA (Buckbinder \& Brown 1993), followed by the ribosomal protein L8 cDNA (rpL8; Shi \& Liang 1994). Analysis of rpL8 allowed for normalization for RNA loading as it is constitutively expressed throughout metamorphosis and its expression is not altered by $\mathrm{TH}$ treatments (Shi \& Liang 1994). Blots were hybridized using ULTRAhyb (Ambion, Austin, TX, USA) and washed following the manufacturer's protocol. Blots were then exposed to BioMax X-ray film (Eastman Kodak, Rochester, NY, USA) for 16-48 h prior to densitometric analysis using Scion Image (see below). Individual replicate RNA samples from each treatment were analyzed on a single gel and each treatment was replicated three times (i.e. three separate gels were analyzed).

\section{Semi-quantitative RT-PCR analysis of pituitary gene expression during metamorphosis}

Semi-quantitative RT-PCR was employed to compare the expression of 13 different genes in tadpole pituitaries throughout metamorphosis (see Table 1 and Figs 4-7). Total RNA was extracted from a pool of 5 pituitaries from each NF developmental stage: 52, 54, 57, 59, 62, and 64. RNA extractions and $\mathrm{RT}$ reactions for each of the six developmental stages studied were conducted simultaneously and the experiment was replicated three times. The RT reaction was conducted on the entire RNA sample and included a 30-min DNase digestion step adapted from Huang et al. (1996). Briefly, 1.5 U RNase-free DNase I (Roche, Indianapolis, IN, USA), $20 \mathrm{U}$ RNase inhibitor (Roche) and $4 \mu \mathrm{l}$ first-strand buffer (Invitrogen; 250 mM Tris-HCl, pH 8.3; 375 mM KCl; $15 \mathrm{mM} \mathrm{MgCl}_{2}$ ) were added to each RNA sample to a final volume of $15 \mu \mathrm{l}$. The digestion proceeded for $30 \mathrm{~min}$ at $37^{\circ} \mathrm{C}$ and samples were then heat-inactivated at $75{ }^{\circ} \mathrm{C}$ for $5 \mathrm{~min}$. The $\mathrm{RT}$ reaction was conducted using SuperScript II RNase $\mathrm{H}^{-}$reverse transcriptase (Invitrogen) according to the manufacturer's protocol using $250 \mathrm{ng}$ of random hexamer primers (Invitrogen) and a 10 -min denaturation step at $70^{\circ} \mathrm{C}$. Each $\mathrm{RT}$ reaction was diluted with $180 \mu \mathrm{l}$ nuclease-free water for a final concentration of 0.025 pituitary equivalents of reverse transcribed RNA (cDNA) per microliter. PCR for several genes conducted on 10 independent minus $\mathrm{RT}$ reactions failed to amplify any gene products, thus confirming that there was no genomic DNA contamination in our RT reactions.

\section{PCR amplification and developmental gene expression analysis}

PCR was conducted using HotStar Taq DNA polymerase following the manufacturer's protocol (Qiagen, Valencia, CA, USA). Deoxyoligonucleotide primer sequences used for each of the 13 genes analyzed are listed in Table 1. Reaction volumes were 25 or $50 \mu \mathrm{l}$, and contained $0 \cdot 05-$ $0 \cdot 15$ pituitary equivalents of reverse transcribed pituitary RNA. Subsequent to an initial 15-min denaturation and activation step at $95^{\circ} \mathrm{C}, \mathrm{PCR}$ cycling conditions were as follows: $94{ }^{\circ} \mathrm{C}$ for $45 \mathrm{~s} ; 52-63{ }^{\circ} \mathrm{C}$ for $45 \mathrm{~s} ; 72{ }^{\circ} \mathrm{C}$ for $60 \mathrm{~s}$. Reactions were cycled 26-42 times depending on the target gene, followed by extension at $72{ }^{\circ} \mathrm{C}$ for $10 \mathrm{~min}$ (Table 1). The number of cycles used for each gene was empirically determined using a linear amplification range beginning at 21 cycles and increasing to 45 cycles in 3 cycle increments. The midpoint of the linear part of the amplification curve was chosen as the optimal number of cycles for each gene (see Table 1). Individual PCR reactions were conducted for each of the 13 genes examined. For each gene, RT-PCR analysis of the six developmental stages was conducted simultaneously and analyzed on a single gel. Three separate RNA pools were analyzed from each developmental stage. PCR products were electrophoresed in a 1.5\% agarose gel and the bands stained with ethidium bromide. Stained bands were captured digitally using a closed-circuit television (CCT) camera and densitometric analyses of these data were conducted using Scion Image (see below).

\section{Data and statistical analyses}

Autoradiographic films were digitized using a flatbed scanner. Images of ethidium bromide-stained gels were captured using a CCT digital camera. Densitometric analysis was conducted using Scion Image software (v. 3.0 Scion Corporation, Frederick, MD, USA) following adjustment for differences in background. Band densities were expressed as the optical density (OD) $\times \mathrm{mm}^{2}$.

Statistical analyses were conducted using the SAS computer program (v. 8.0, SAS Institute Inc., Cary, NC, USA). All statistical analyses on densitometric data were conducted on the raw, untransformed data. Pituitary explant culture data were analyzed for statistically significant differences in TSH $\beta$ and $\alpha$-GSU expression using a blocks design ANOVA, with each experimental replicate 
Table 1 Primer sequences and polymerase chain reaction (PCR) conditions employed to amplify 13 different genes from X. laevis pituitary RNA using semiquantitative reverse transcription PCR

\begin{tabular}{|c|c|c|c|c|c|}
\hline & Primer (sense above, antisense below) & $\begin{array}{l}\text { PCR } \\
\text { product } \\
\text { (bp) }\end{array}$ & $\begin{array}{l}\text { Annealing } \\
\text { temperature } \\
\left({ }^{\circ} \mathrm{C}\right)\end{array}$ & $\begin{array}{l}\text { No. of } \\
\text { cycles }\end{array}$ & $\begin{array}{l}\text { GenBank } \\
\text { accession } \\
\text { number }\end{array}$ \\
\hline rpL8 & CAGGATGGGTTTGTCAATACG & & & & \\
\hline \multirow[t]{2}{*}{$\alpha$-GSU } & GGTTCAGGGATGCCCAGAATGTA & 326 & 63 & 26 & L07619 \\
\hline & GAGGGAAGGACAGCCAAGAAACA & & & & \\
\hline $\mathrm{TSH} \beta$ & GCCGAGATATTGAGGCTCGAATGGTTT & & & & \\
\hline \multirow[t]{2}{*}{$T R \beta A$} & GGCAACAGACTTGGTTTTGG & 275 & 57 & 36 & M35359 \\
\hline & AAGTCCACTTTTCСАСССТС & & & & \\
\hline \multirow{2}{*}{ DIl } & AGCCATAAATAGССТGСССТGTG & 278 & 57 & 34 & AF354707 \\
\hline & GGAACCTTAACTTTGGGACTGC & & & & \\
\hline \multirow[t]{2}{*}{ DIII } & TACATCGTCCTGGAGGGCAAAG & 490 & $61 \cdot 1$ & 35 & L28111 \\
\hline & ТТАТТТСGСААТGАСАТСТGАACС & & & & \\
\hline \multirow[t]{2}{*}{ TRH-R2 } & TGCСАTTGTGСТСАТАTTACAGA & 407 & 57 & 39 & AF305621 \\
\hline & TCCAGCGGCTACCAAGACCATT & & & & \\
\hline \multirow[t]{2}{*}{ CRF } & TСТССТGССТGСТСТGTССАA & 321 & $61 \cdot 1$ & 35 & S50096 \\
\hline & СТTGCСАTTСТАAGACTTCACGG & & & & \\
\hline \multirow[t]{2}{*}{$\mathrm{CRF}_{1}$} & GATCTAAATAGCAGGATGCTGTTGGC & 288 & $62 \cdot 6$ & 35 & Y14036 \\
\hline & GCCGTTCAGGTGACATTCTCTGTAC & & & & \\
\hline \multirow[t]{2}{*}{$\mathrm{CRF}_{2}$} & GTACСТСССАСАТСССАСАGСТTCAC & 308 & $62 \cdot 6$ & 37 & Y14037 \\
\hline & GACGCCCAGGTTCCATTCTCAAAGC & & & & \\
\hline \multirow[t]{2}{*}{ CRF-BP } & TGACTCСТGСТTCCAGАССТ & 452 & 61 & 39 & U41858 \\
\hline & TGACСТTGTAATGСТССССАС & & & & \\
\hline
\end{tabular}

rpL8, ribosomal protein L8; $\alpha$-GSU, $\alpha$ glycoprotein subunit; TSH $\beta$, thyrotropin $\beta$ subunit; TR $\beta$ A, thyroid hormone receptor $\beta$ A; DII, deiodinase type II; DIII, deiodinase type III; TRH, thyrotropin-releasing hormone; TRH-R1, TRH receptor type 1; TRH-R2, TRH receptor type 2; CRF, corticotropin-releasing factor; $\mathrm{CRF}_{1}, \mathrm{CRF}$ receptor type $1 ; \mathrm{CRF}_{2}$, CRF receptor type 2; CRF-BP, CRF-binding protein.

representing a single block. Data were analyzed following removal of variation due to RNA (and subsequent cDNA) loading using the level of rpL8. Following acceptance of the entire ANOVA model as statistically significant, the data were tested for any statistically significant stage-bytreatment effects. Stage-by-treatment effects were not observed, thus the data for all three developmental stages were pooled and the ANOVA model was used to test for differences between experimental groups following the removal of the variation due to developmental stage. This step in the ANOVA model facilitated a threefold increase in sample size, thus increasing the statistical power of the model. The Dunn-Šidák multiple comparison method (a modification of the sequential Bonferroni test) was used to test for pair-wise differences between experimental groups (Ury 1976, Sokal \& Rohlf 1981). Means were accepted as statistically significant if $P<0 \cdot 05$. The mean $\alpha-G S U$ and TSH $\beta$ gene expression data from the 3 replicates of each experimental group and stage are presented graphically as a percentage of the expression in the control group following normalization for differences in $\mathrm{rpL} 8$ gene expression for both dose-response experiments.

A blocks design ANOVA, with each experimental replicate representing a single block, was used to test for statistically significant differences in pituitary gene expression during metamorphosis. All statistical analyses were conducted on raw untransformed, densitometric data. This model was used to identify statistically significant differences between metamorphic stages for 12 different genes following correction for differences in starting total RNA as determined by $\mathrm{rpL} 8$ expression. The Dunn-Šidák multiple comparison test was used to test for pair-wise differences between developmental stages (Ury 1976, Sokal \& Rohlf 1981). Differences between means were accepted as statistically significant if $P<0 \cdot 05$. The means of three experimental replicates for each gene studied are presented graphically as a percentage of the developmental stage with the highest expression level, following normalization for differences in $\mathrm{rpL} 8$. 


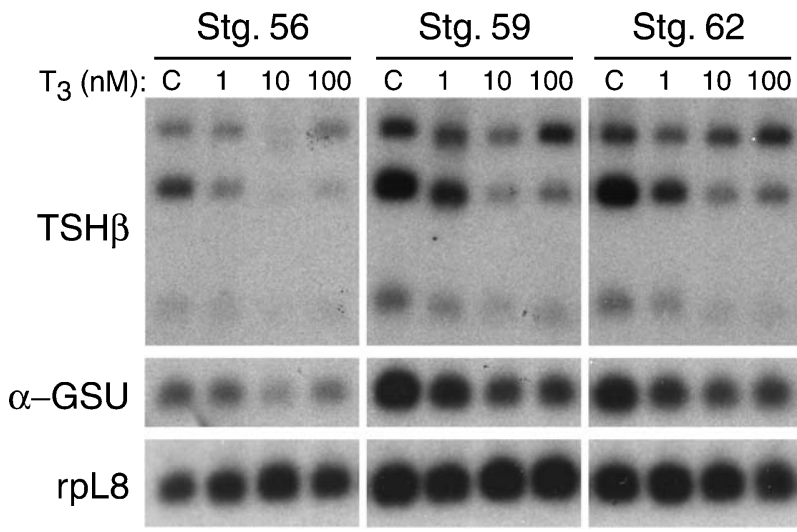

Figure 1 A representative Northern blot of thyrotropin $\beta$ (TSH), $\alpha$-glycoprotein subunit ( $\alpha$-GSU) and ribosomal protein L8 (rpL8) mRNA expression by cultured $X$. laevis tadpole pituitaries at three different Nieuwkoop and Faber (1956) stages (Stg.). Following a 20-h preincubation period to stabilize TSH gene expression and secretion, pituitaries were incubated in the presence of $0,1,10$ or $100 \mathrm{nM}$ triiodothyronine $\left(\mathrm{T}_{3}\right)$ for $24 \mathrm{~h}$ before harvest.

\section{Results}

\section{Pituitary explant experiments}

In vitro dose-response experiments were conducted to determine whether negative feedback on pituitary TSH gene expression is operative throughout metamorphosis, and whether the dose sensitivity to $T_{3}$ or $T_{4}$ changes with development. Overall, both $\mathrm{T}_{3}$ and $\mathrm{T}_{4}$ lowered $\mathrm{TSH}$ expression by pituitaries cultured in vitro, independent of developmental stage. Negative feedback inhibition on TSH $\beta$ and $\alpha$-GSU expression by TH was observed at all stages tested (i.e. NF stages 56, 59, 62; Figs 1 - 3). No significant stage-by-treatment effect was observed for either $\mathrm{T}_{3}$ (TSH $\beta$ : $P=0.6278, \mathrm{~F}=0.78$, degrees of freedom $(\mathrm{df})=8 ; \alpha$-GSU: $P=0 \cdot 0958, \mathrm{~F}=1 \cdot 98, \mathrm{df}=8)$ or $\mathrm{T}_{4}(\mathrm{TSH} \beta$ : $P=0 \cdot 2326, \mathrm{~F}=1 \cdot 43, \mathrm{df}=8 ; \alpha-\mathrm{GSU}: P=0 \cdot 7134, \mathrm{~F}=0.67$, $\mathrm{df}=8)$; that is, the sensitivity of pituitaries from stage 56 , 59 and 62 tadpoles to $\mathrm{TH}$ did not differ significantly between stages. Despite the lack of a statistically significant stage-by-treatment effect, pituitaries from early prometamorphic tadpoles (i.e. stage 56) tended to be more sensitive to both $\mathrm{T}_{4}$ and $\mathrm{T}_{3}$ than the other stages tested, with respect to the downregulation of TSH $\beta$ expression. Following exposure to $1 \mathrm{nM} \mathrm{T}$, TSH $\beta$ mRNA levels in stage 56 pituitaries were $32 \%$ of control levels in comparison with 66 and $83 \%$ of control levels for stages 59 and 62 respectively (Figs 1 and 2). A similar trend, although also not significant, suggesting that stage 56 pituitaries were most sensitive to $\mathrm{TH}$ was observed following treatment with 10 and $100 \mathrm{nM} \mathrm{T}_{3}$ as well as 1 and $10 \mathrm{nM} \mathrm{T}$ (Fig. 2). For reference, peak whole body and serum $\mathrm{T}_{3}$ and $\mathrm{T}_{4}$ concentrations in $X$. laevis tadpoles range from 8 to $12 \mathrm{nM}$ and from 7 to $10 \mathrm{nM}$ respectively (Leloup \& Buscaglia 1977, Krain \& Denver 2004). Thus, TH

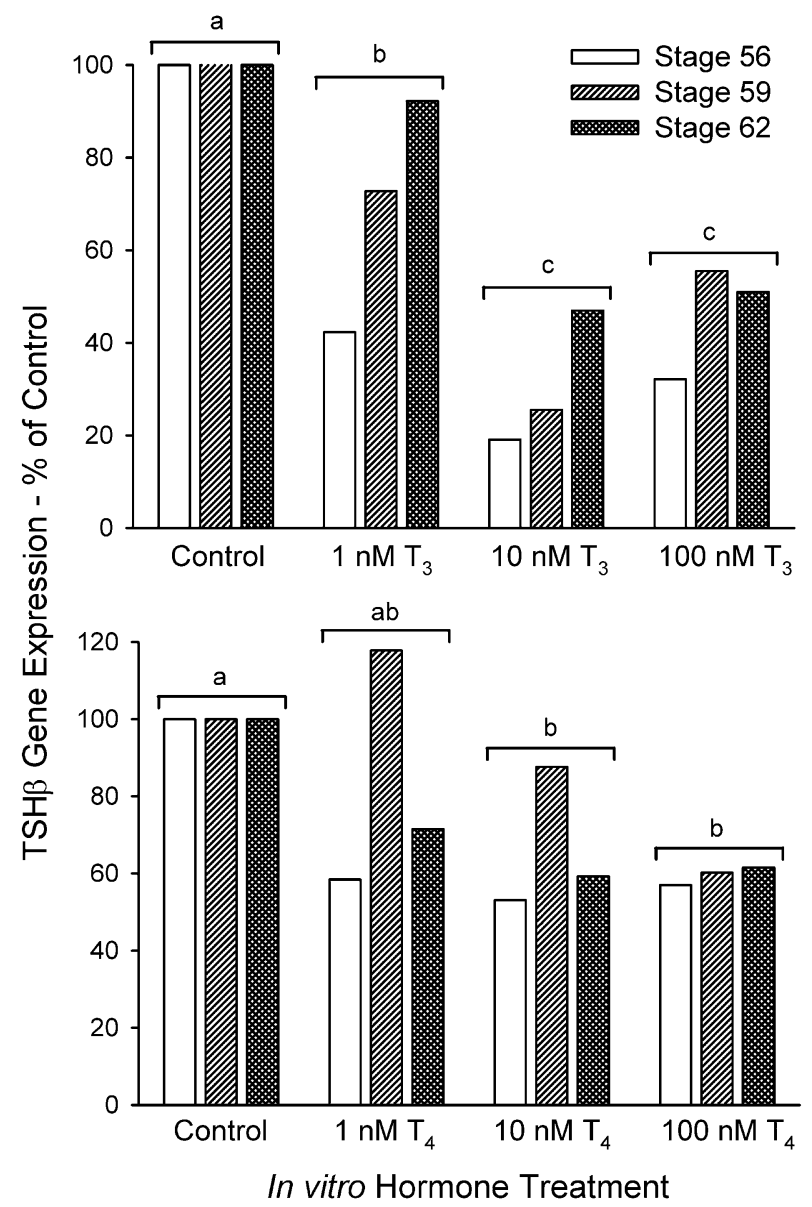

Figure 2 Thyrotropin $\beta$ (TSH $\beta$ ) gene expression by cultured pituitaries derived from $X$. laevis tadpoles at three different Nieuwkoop and Faber (1956) stages. Pituitaries were preincubated for $20 \mathrm{~h}$ to allow for stabilization of TSH gene expression and secretion, and then incubated in the presence or absence of triiodothyronine $\left(\mathrm{T}_{3}\right)$ or thyroxine $\left(\mathrm{T}_{4}\right)$ for an additional $24 \mathrm{~h}$ before harvest. TSH $\beta$ mRNA levels were normalized to the housekeeping gene ribosomal protein L8 (rpL8). Values are expressed as a percentage of control levels and are the mean of 3 replicates. Analysis of variance indicated significant differences between experimental groups $\left(\mathrm{T}_{3}: P=0 \cdot 0010, \mathrm{~F}=7 \cdot 12, \mathrm{df}=4 ; \mathrm{T}_{4}: P=0 \cdot 0011\right.$, $\mathrm{F}=6 \cdot 29, \mathrm{df}=4$; corrected for differences in stage) and developmental stages $\left(\mathrm{T}_{3}: P=0.0052, \mathrm{~F}=6.93, \mathrm{df}=2 ; \mathrm{T}_{4}\right.$ : $P=0.0015, F=8 \cdot 40, d f=2$; corrected for differences in experimental group); however, no stage-by-treatment interaction effect was observed $\left(\mathrm{T}_{3}: P=0 \cdot 6278, \mathrm{~F}=0 \cdot 78, \mathrm{df}=8 ; \mathrm{T}_{4}: P=0 \cdot 2326\right.$, $\mathrm{F}=1 \cdot 43, \mathrm{df}=8$ ). Pair-wise differences (Dunn-Šidák multiple comparison test) were accepted as statistically significant if $P<0 \cdot 05$. Experimental groups labeled with different letters indicate statistically significant differences. All statistical analyses on densitometric data were conducted on the raw untransformed data following removal of variation due to RNA (and subsequent cDNA) loading using the level of rpL8.

concentrations within the normal physiological range for $X$. laevis tadpoles suppress pituitary TSH expression. The negative effects of TH on $\alpha$-GSU expression were similar 


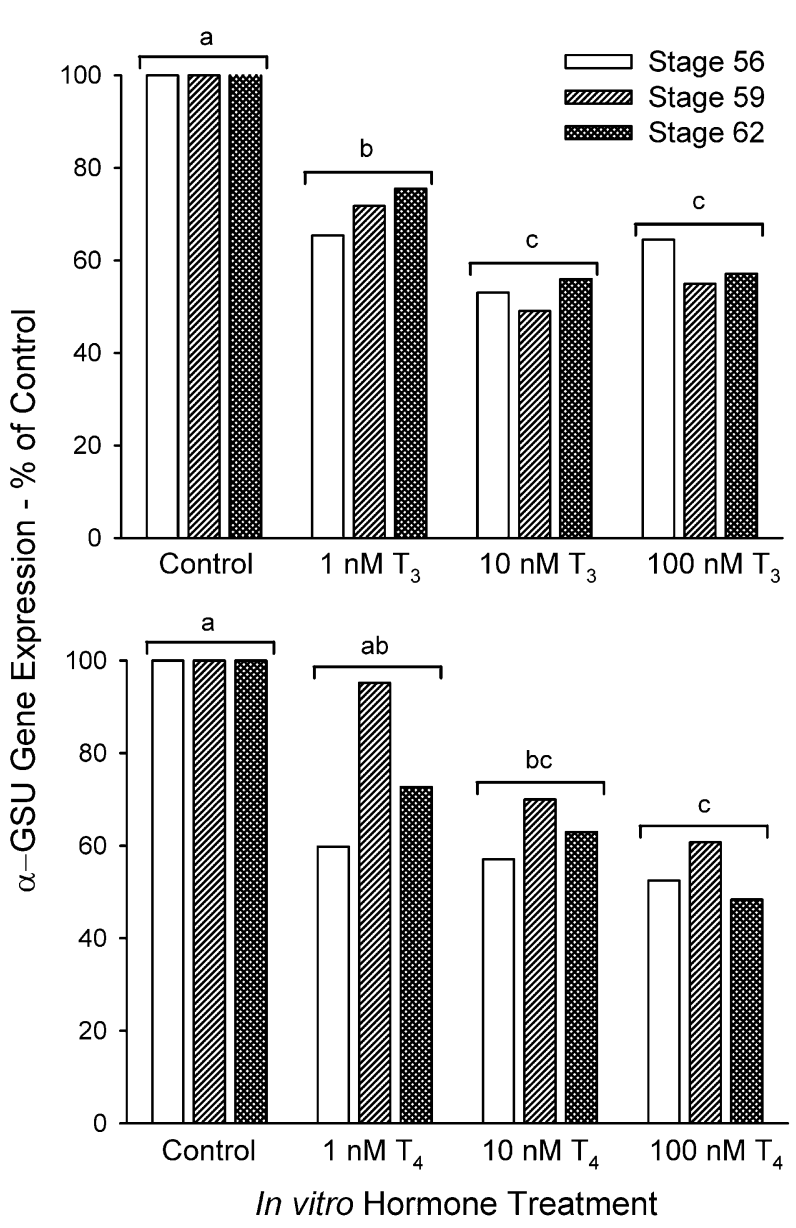

Figure 3 Alpha glycoprotein subunit ( $\alpha$-GSU) gene expression by cultured pituitaries derived from $X$. laevis tadpoles at three different Nieuwkoop and Faber (1956) stages. Pituitaries were preincubated for $20 \mathrm{~h}$ to allow for stabilization of $\alpha$-GSU gene expression and secretion, and then incubated in the presence or absence of triiodothyronine $\left(\mathrm{T}_{3}\right)$ or thyroxine $\left(\mathrm{T}_{4}\right)$ for an additional $24 \mathrm{~h}$ before harvest. $\alpha$-GSU mRNA levels were normalized to the

housekeeping gene ribosomal protein L8 (rpL8). Values are expressed as a percentage of control levels and are the mean of 3 replicates. Analysis of variance indicated significant differences between experimental groups $\left(\mathrm{T}_{3}: P<0 \cdot 0001, \mathrm{~F}=17 \cdot 36, \mathrm{df}=4\right.$; $\mathrm{T}_{4}: P<0 \cdot 0001, \mathrm{~F}=12 \cdot 77, \mathrm{df}=4$; corrected for differences in stage) and developmental stages $\left(\mathrm{T}_{3}: P=0 \cdot 0012, \mathrm{~F}=9 \cdot 16, \mathrm{df}=2\right.$; $\mathrm{T}_{4}: P=0 \cdot 0002, \mathrm{~F}=12 \cdot 18, \mathrm{df}=2$; corrected for differences in experimental group); however, no stage-by-treatment interaction effect was observed $\left(\mathrm{T}_{3}: P=0.0958, \mathrm{~F}=1.98, \mathrm{df}=8 ; \mathrm{T}_{4}: P=0.7134\right.$, $\mathrm{F}=0 \cdot 67, \mathrm{df}=8$ ). Pair-wise differences (Dunn-Šidák multiple comparison test) were accepted as statistically significant if $P<0 \cdot 05$. Experimental groups labeled with different letters indicate statistically significant differences. All statistical analyses on densitometric data were conducted on the raw untransformed data following removal of variation due to RNA (and subsequent CDNA) loading using the level of rpL8.

for all three developmental stages examined with no evidence for differences in sensitivity among stages (Fig. 3).
The absence of any significant stage-by-treatment interaction in the ANOVA model permitted the pooling of all stages examined to test for statistically significant differences between experimental groups (i.e. thyroid hormone treatment dose). Both $\mathrm{T}_{4}$ and $\mathrm{T}_{3}$ significantly reduced TSH $\beta \quad\left(\mathrm{T}_{4}: P=0.0011, \quad \mathrm{~F}=6.29, \quad \mathrm{df}=4 ; \mathrm{T}_{3}\right.$ : $P=0 \cdot 0010, \mathrm{~F}=7 \cdot 12, \mathrm{df}=4)$ and $\alpha-\mathrm{GSU}\left(\mathrm{T}_{4}: P<0 \cdot 0001\right.$, $\left.\mathrm{F}=12 \cdot 77, \mathrm{df}=4 ; \mathrm{T}_{3}: P<0 \cdot 0001, \mathrm{~F}=17 \cdot 36, \mathrm{df}=4\right)$ expression levels (Figs 2 and 3); however, pituitaries were approximately 10 times more sensitive to $T_{3}$ than $T_{4}$. Consistent with data from rodent TSH-secreting tumor cells (Shupnik et al. 1985), TSH $\beta$ was downregulated to a greater extent than $\alpha$-GSU. The lowest $\mathrm{TH}$ treatment dose tested was $1 \mathrm{nM}$; this dose of $\mathrm{T}_{3}$ significantly downregulated both TSH $\beta$ and $\alpha$-GSU expression. However, a treatment dose of $10 \mathrm{nM} \mathrm{T}_{4}$ was required to reduce either TSH $\beta$ or $\alpha$-GSU expression levels below control values. Consistent with pituitaries being more responsive to $T_{3}$ than $T_{4}$ treatments was the observation that the decline in TSH expression levels tended to be greater following treatment with $T_{3}$ than with $T_{4}$. The lowest TSH $\beta$ expression levels were observed following treatment with $10 \mathrm{nM} \mathrm{T}_{3}$ (24\% of control values). In contrast, the $\mathrm{T}_{4}$ concentration that produced the greatest reduction in TSH $\beta$ expression levels was $100 \mathrm{nM}$, where expression levels were $59 \%$ of control values (Fig. 2). A similar trend was observed for $\alpha$-GSU expression with $10 \mathrm{nM} \mathrm{T}_{3}$ being as effective at lowering expression levels as $100 \mathrm{nM} \mathrm{T}_{4}$ (Fig. 3). Maximal decreases in TSH $\beta$ and $\alpha-G S U$ expression levels were as follows: $10 \mathrm{nM} \mathrm{T} \mathrm{T}_{3}$ reduced TSH $\beta$ expression to $24 \%$ of control levels, whereas $\alpha$-GSU expression was reduced to only $52 \%$ of control levels following the same treatment.

\section{Developmental expression of pituitary genes}

Thyrotropin, thyroid hormone receptor $\beta A$ and $T H$ deiodinases We observed a strong and steady increase (fivefold) in TSH $\beta$ and $\alpha$-GSU expression levels from stage 52 to peak values at stage 59 after which expression levels declined slightly (TSH $\beta: \quad P=0 \cdot 0017, \quad F=11 \cdot 52, \quad d f=5 ; \alpha$-GSU: $P=0 \cdot 0015, \mathrm{~F}=11 \cdot 99, \mathrm{df}=5$; Fig. 4). Pair-wise multiple comparison tests detected significant increases in TSH $\beta$ and $\alpha$-GSU expression levels between stages 52 and 54 , as well as 54 and 59. However, the decline in TSH $\beta$ and $\alpha$-GSU expression following the peak values at stage 59 was not statistically significant (Fig. 4).

Thyroid hormone receptor $\beta A$ (TR $\beta A$ ) expression levels were at their lowest during premetamorphosis (stages 52 and 54), increased throughout prometamorphosis (stages 57 and 59), peaked at metamorphic climax (stage 62) and remained elevated at stage 64 (Fig. 5). Overall, the observed changes in TR $\beta$ A expression levels during metamorphosis were statistically significant $(P=0 \cdot 0357$, $\mathrm{F}=4 \cdot 58, \mathrm{df}=5)$; however, multiple comparison tests did not identify any significant pair-wise differences $(P>0 \cdot 05)$ between specific developmental stages (Fig. 5). 


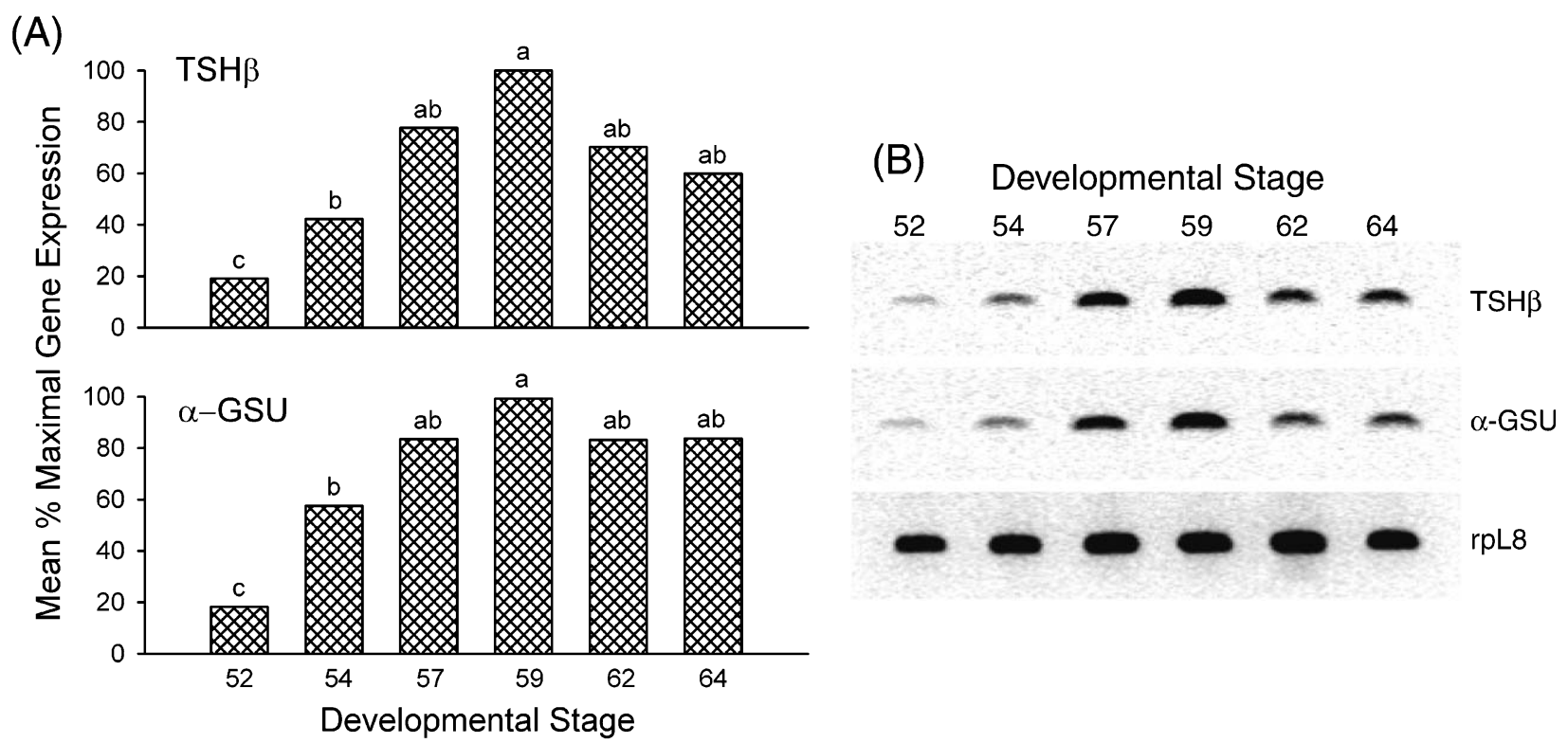

Figure 4 Pituitary thyrotropin $\beta$ (TSH $\beta$ ) and $\alpha$-glycoprotein subunit ( $\alpha$-GSU) mRNA expression during metamorphosis of $X$. laevis. RNAs were analyzed by semi-quantitative RT-PCR as described in Materials and Methods. (A) Normalized densitometric values for TSH $\beta$ and $\alpha$-GSU mRNAs. Values represent the mean percent maximal gene expression relative to the developmental stage with the highest expression for 3 replicates ( 5 pituitaries per replicate). Data were normalized for variation in RNA (and subsequently cDNA) loading using ribosomal protein L8 (rpL8) expression. Significant differences between stages were observed for both TSH $\beta(P=0 \cdot 0017, \mathrm{~F}=11 \cdot 52$, $\mathrm{df}=5$; ANOVA) and $\alpha$-GSU $(P=0.0015, \mathrm{~F}=11.99, \mathrm{df}=5$; ANOVA). Pair-wise differences (Dunn-Šidák multiple comparison test) were accepted as statistically significant if $P<0 \cdot 05$. Experimental groups labeled with different letters indicate statistically significant differences. All statistical analyses on densitometric data were conducted on the raw untransformed data following removal of variation due to RNA (and subsequent CDNA) loading using the level of rpL8. (B) Representative ethidium bromide-stained gels (negative image) following RT-PCR are shown.

The developmental expression patterns of the iodothyronine deiodinases type II and III (DII and DIII respectively) followed a trend similar to that observed for TSH and TR $\beta$ A expression. Expression levels of the two deiodinases increased in parallel throughout metamorphosis and remaining elevated at the end of metamorphosis (Fig. 5). In the case of DIII gene expression, the observed differences were significant $(P=0 \cdot 0004, \mathrm{~F}=15 \cdot 1$, $\mathrm{df}=5)$, but in the case of DII they were marginally nonsignificant $(P=0 \cdot 0581, \mathrm{~F}=3 \cdot 28, \mathrm{df}=5)$. See Fig. 5 for pair wise differences in DIII gene expression between developmental stages.

Neuropeptides, neuropeptide receptors and CRF binding protein Both CRF and TRH genes were expressed in the tadpole pituitary throughout metamorphosis, but significant differences between stages were not detected (CRF: $P=0 \cdot 0966, \mathrm{~F}=2 \cdot 65, \mathrm{df}=5 ; \mathrm{TRH}: P=0 \cdot 1149, \mathrm{~F}=2 \cdot 45$, $\mathrm{df}=5$; Figs 6 and 7 respectively). Despite the lack of statistical significance, TRH expression in the pituitary appeared to show a biphasic pattern. TRH expression increased from stage 52 to 57 , decreased briefly at stage 59 , only to increase slightly at stage 62 and finally decrease again at stage 64 (Fig. 7).
Pituitary expression of the CRF binding protein (CRF$\mathrm{BP})$ tended to increase throughout prometamorphosis, peak at climax and decline at the end of metamorphosis; however, these differences were not statistically significant $(P=0 \cdot 2148, \mathrm{~F}=1 \cdot 77, \mathrm{df}=5$; Fig. 6). Pituitary expression of CRF receptor types 1 and $2\left(\mathrm{CRF}_{1}\right.$ and $\mathrm{CRF}_{2}$ respectively) increased steadily from stage 52 to stage 59 and remained elevated through stage 64 (Fig. 6). Although the Dunn-Šidák multiple comparison test did not identify any pair-wise differences, the ANOVA model indicated that the $\mathrm{CRF}_{2}$ mRNA expression levels varied significantly $(P=0 \cdot 0312, \mathrm{~F}=4 \cdot 15, \mathrm{df}=5)$ with metamorphic stage. It is also noteworthy that the differences in $\mathrm{CRF}_{1}$ mRNA expression levels between stages were marginally nonsignificant $(P=0 \cdot 0571, \mathrm{~F}=3 \cdot 31, \mathrm{df}=5)$.

In contrast to the parallel increase in expression of $\mathrm{CRF}_{1}$ and $\mathrm{CRF}_{2}$ throughout metamorphosis, TRH receptors 1 and 2 (TRH-R1 and TRH-R2) exhibited divergent patterns of expression in tadpole pituitaries. TRH-R1 mRNA tended to decrease towards the end of metamorphosis (stages 62 and 64), although this was not statistically significant $(P=0 \cdot 8288 ; \mathrm{F}=0 \cdot 41, \mathrm{df}=5)$. On the other hand, expression levels of TRH-R2 were relatively low during stages 52 and 54 , increased threefold by stage 


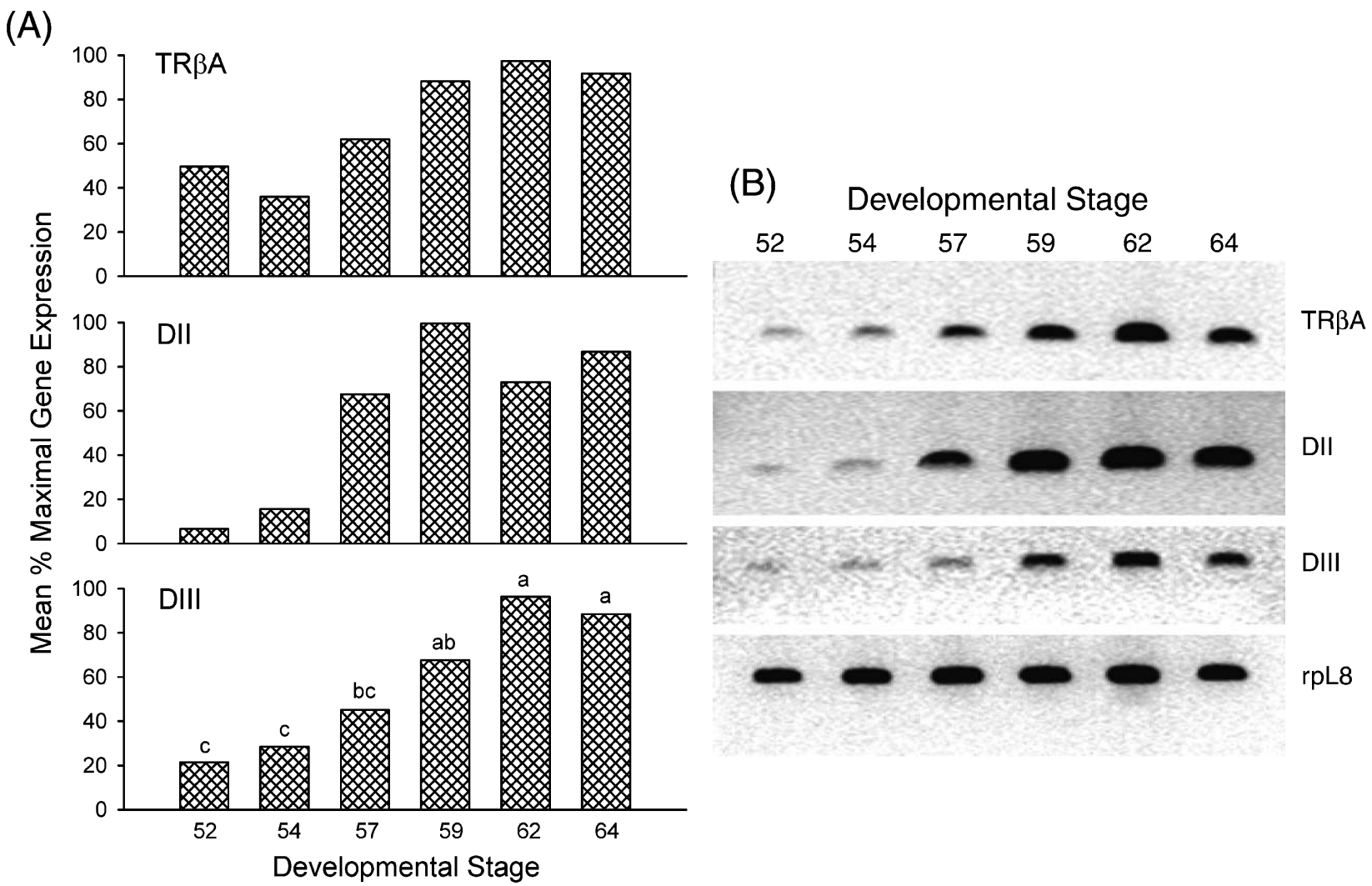

Figure 5 Pituitary thyroid hormone receptor $\beta$ A (TR $\beta A$ ), deiodinase type II (DII) and deiodinase type III (DIII) mRNA expression during metamorphosis of $X$. laevis. RNAs were analyzed by semi-quantitative RT-PCR as described in Materials and Methods. (A) Normalized densitometric values for TR $\beta A$, DII and DIII. Values represent the mean percent maximal gene expression relative to the developmental stage with the highest expression for 3 replicates ( 5 pituitaries per replicate). Data were normalized for variation in RNA (and subsequently CDNA) loading using ribosomal protein L8 (rpL8) expression. Significant differences between stages were observed for TRßA $(P=0.0357, \mathrm{~F}=4 \cdot 58, \mathrm{df}=5$; ANOVA $)$, and DIII $(P=0 \cdot 0004, \mathrm{~F}=15 \cdot 10, \mathrm{df}=5$; ANOVA $)$. Differences in DII expression were marginally nonsignificant $(P=0 \cdot 0581, \mathrm{~F}=3 \cdot 28, \mathrm{df}=5$; ANOVA). Pair-wise differences (Dunn-Šidák multiple comparison test) were accepted as statistically significant if $P<0 \cdot 05$. Experimental groups labeled with different letters indicate statistically significant differences. The absence of letters for TR $\beta A$ and DII indicates that no significant pair-wise differences were detected. All statistical analyses on densitometric data were conducted on the raw untransformed data following removal of variation due to RNA (and subsequent cDNA) loading using the level of rpL8. (B) Representative ethidium bromide-stained gels (negative image) following RT-PCR are shown.

57 and remained elevated through stage $64(P=0 \cdot 0031$, $\mathrm{F}=18 \cdot 49, \mathrm{df}=5)$. Pair-wise multiple comparison tests indicated that the increase in TRH-R2 expression between stages 54 and 57 was statistically significant (Fig. 7).

\section{Discussion}

We used pituitary explant cultures to test whether $T_{4}$ or $\mathrm{T}_{3}$ can act directly on the $X$. laevis tadpole pituitary gland to suppress TSH gene expression, and to assess whether this negative feedback changes during metamorphosis. Our results clearly show that treatment with physiological concentrations (Leloup \& Buscaglia 1977, Krain \& Denver 2004) of either $T_{4}$ or $T_{3}$ can act directly on pituitaries from stage 56, 59 and $62 \mathrm{X}$. laevis tadpoles to suppress TSH
mRNA expression; hence, negative feedback at the level of the pituitary is active from early prometamorphosis (Figs 2 and 3). We observed no significant differences between stages with respect to the effects of TH treatment on TSH mRNA levels, although pituitaries derived from stage 56 tadpoles tended to exhibit the greatest negative feedback response (Figs 2 and 3). This is the first study to clearly demonstrate that $\mathrm{TH}$ can act directly on the tadpole pituitary throughout prometamorphosis and metamorphic climax to negatively regulate TSH. Indirect evidence supporting the presence of negative feedback early in tadpole development dates back to the early 1960s. Studies conducted on both R. pipiens (Kaye 1961) and X. laevis (Dodd \& Dodd 1976) showed that treatment with TH suppressed thyroidal activity as measured by a decrease in iodide uptake by the thyroid gland. Similarly, treatment of premetamorphic tadpoles with goitrogens resulted in 
(A)
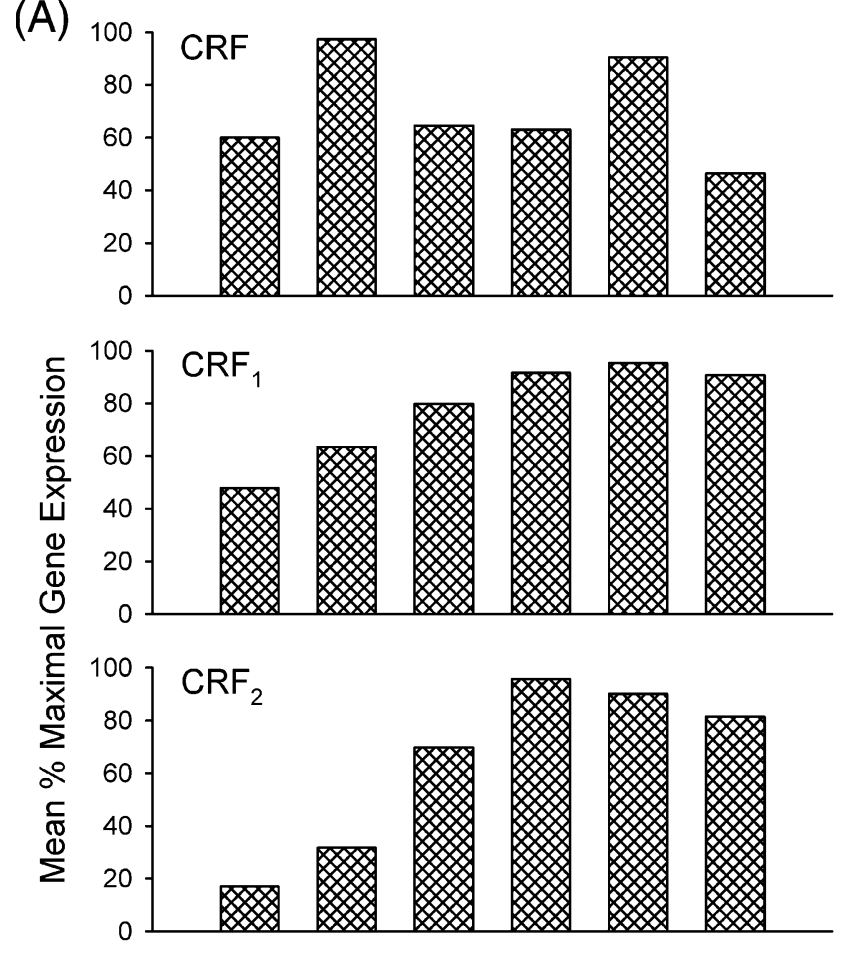

(B) Developmental Stage
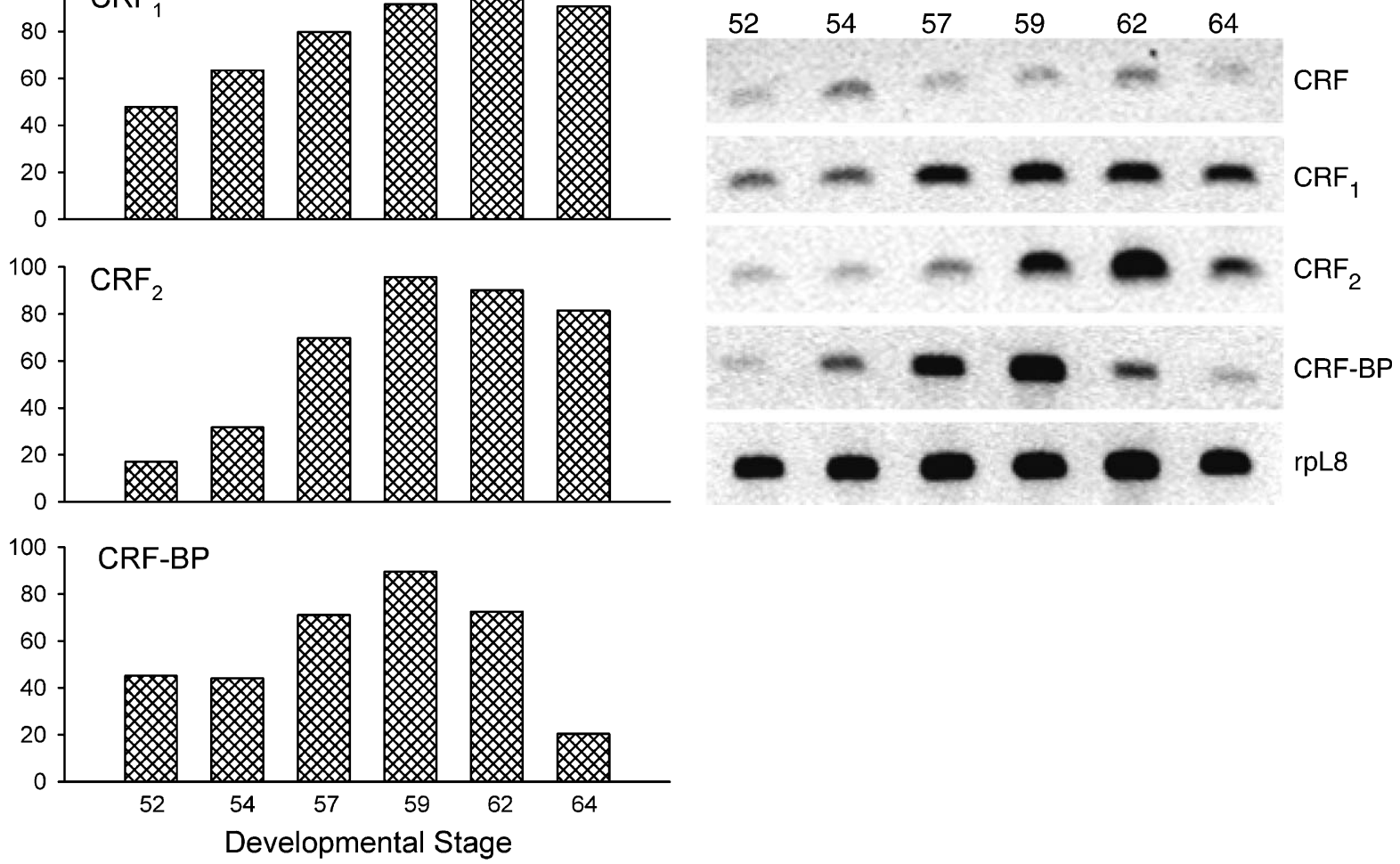

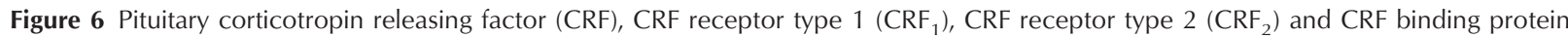
(CRF-BP) mRNA expression during metamorphosis of $X$. laevis. RNAs were analyzed by semi-quantitative RT-PCR as described in Materials and Methods. (A) Normalized densitometric values for CRF, CRF ${ }_{1}, \mathrm{CRF}_{2}$ and CRF-BP. Values represent the mean percent maximal gene expression relative to the developmental stage with the highest expression for 3 replicates ( 5 pituitaries per replicate). Data were normalized for variation in RNA (and subsequently cDNA) loading using ribosomal protein L8 (rpL8) expression. Significant differences between stages were observed for $\mathrm{CRF}_{2}(P=0 \cdot 0312, \mathrm{~F}=4 \cdot 15, \mathrm{df}=5$; ANOVA $)$, but differences were marginally nonsignificant for $\mathrm{CRF}_{1}(P=0.0571, \mathrm{~F}=3 \cdot 31, \mathrm{df}=5$; ANOVA). However, statistically significant differences were not observed for either $\mathrm{CRF}(P=0 \cdot 0966$, $\mathrm{F}=2 \cdot 65, \mathrm{df}=5$; ANOVA) or CRF-BP $(P=0.2148, \mathrm{~F}=1 \cdot 77, \mathrm{df}=5$; ANOVA). Statistically significant $(P<0 \cdot 05)$, pair-wise differences (Dunn-Šidák multiple comparison test) were not detected. All statistical analyses on densitometric data were conducted on the raw untransformed data following removal of variation due to RNA (and subsequent cDNA) loading using the level of rpL8.

(B) Representative ethidium bromide-stained gels (negative image) following RT-PCR are shown.

hypertropy of the thyroid gland (Hanaoka 1967, Dodd \& Dodd 1976, Goos 1978). More recently, it was shown that treatment of early prometamorphic X. laevis tadpoles with the goitrogen, methimazole, elevated pituitary TSH mRNA levels (Buckbinder \& Brown 1993, Huang et al. 2001). Taken together, the accumulated data lead to the rejection of the hypothesis that negative feedback is turned on specifically at metamorphic climax (see Huang et al. 2001).
Huang and colleagues (2001) recently addressed the issue of thyroidal regulation of the pituitary gland during amphibian metamorphosis and the establishment of negative feedback. In their paper, they claim that TH negative feedback on the pituitary of $X$. laevis is established at stage 62 (metamorphic climax) and that this feedback is causally related to the upregulation of DII. They based their conclusions on several lines of evidence: the demonstrated roles of DII and DIII in the differential timing of cell and 


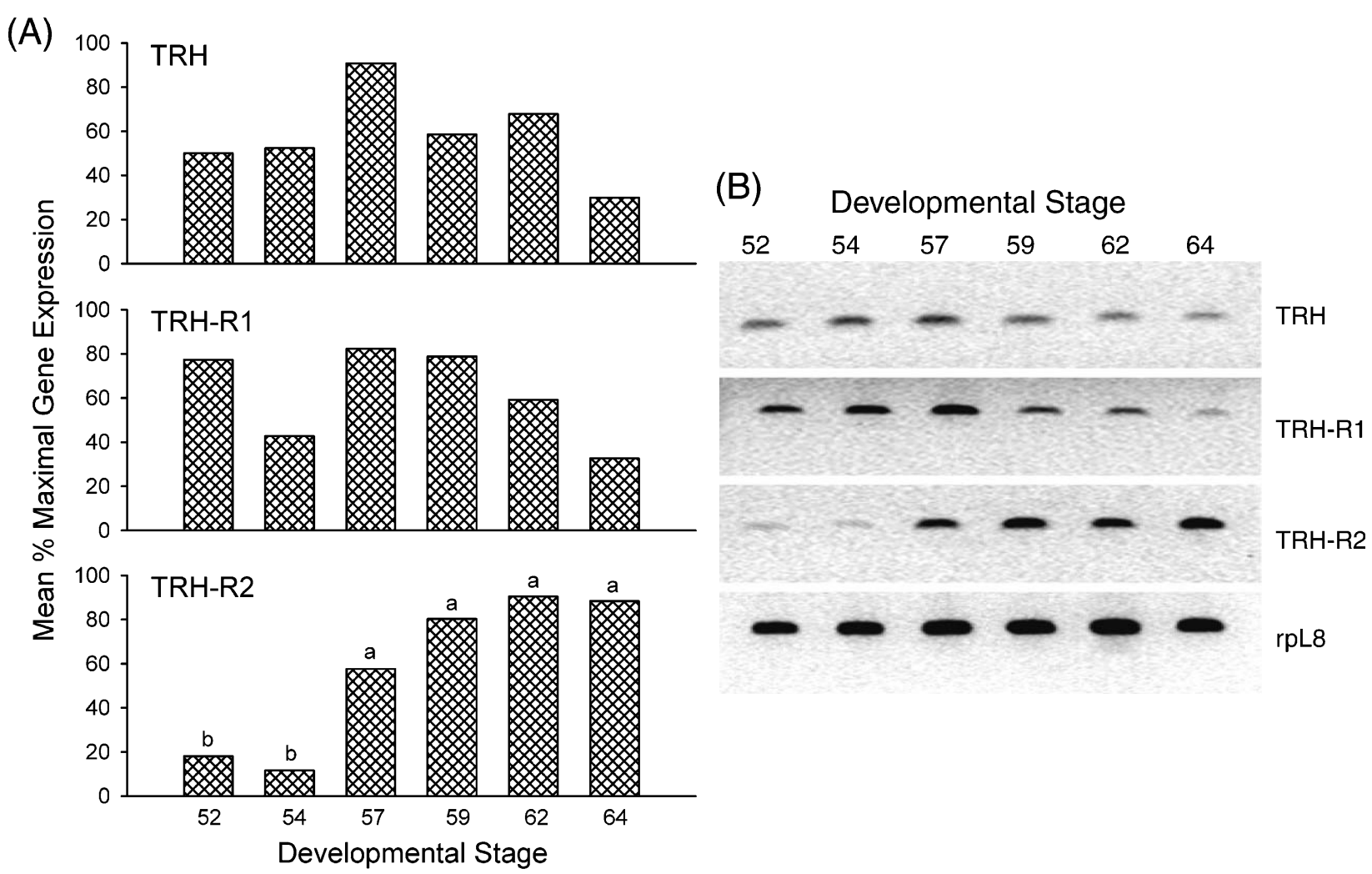

Figure 7 Pituitary thyrotropin releasing hormone (TRH), TRH receptor type 1 (TRH-R1), and TRH receptor type 2 (TRH-R2) mRNA expression during metamorphosis of $X$. laevis. RNAs were analyzed by semi-quantitative RT-PCR as described in Materials and Methods. (A) Normalized densitometric values for TRH, TRH-R1 and TRH-R2. Values represent the mean percent maximal gene expression relative to the developmental stage with the highest expression for 3 replicates ( 5 pituitaries per replicate). Data were normalized for variation in RNA (and subsequently cDNA) loading using ribosomal protein L8 (rpL8) expression. Significant differences between stages observed for TRH-R2 $(P=0 \cdot 0031, F=18 \cdot 49, \mathrm{df}=5$; ANOVA $)$. However, statistically significant differences were not observed for either TRH $(P=0 \cdot 1149$, $\mathrm{F}=2 \cdot 45, \mathrm{df}=5$; ANOVA) or TRH-R1 $(P=0 \cdot 8288, \mathrm{~F}=0 \cdot 41, \mathrm{df}=5$; ANOVA). Pair-wise differences (Dunn-Šidák multiple comparison test) were accepted as statistically significant if $P<0 \cdot 05$. Experimental groups labeled with different letters indicate statistically significant differences. All statistical analyses on densitometric data were conducted on the raw untransformed data following removal of variation due to RNA (and subsequent cDNA) loading using the level of rpL8. (B) Representative ethidium bromide-stained gels (negative image) following RT-PCR are shown.

tissue morphogenesis (Becker et al. 1997, Kawahara et al. 1999, Huang et al. 2001); the presence of DII mRNA at stage 62 of development but not at stage 56 (Huang et al. 2001); the observation that TSH mRNA expression levels increase during metamorphosis, peak at climax and then decline rapidly (Buckbinder \& Brown 1993); and the claim that $\mathrm{T}_{4}$ does not downregulate TSH $\beta$ expression (Huang et al. 2001). However, as discussed earlier, our study along with several earlier studies clearly show that negative feedback is active early in prometamorphosis. Moreover, we showed that DII mRNA is present in pituitaries from early prometamorphic X. laevis. Thus, our data suggest that a mechanism other than the absence of DII expression in pre- and prometamorphic tadpole pituitaries is responsible for the sustained rise in TSH expression during prometamorphosis and metamorphic climax.
If the hypothesis that the upregulation of DII at metamorphic climax is responsible for the establishment of negative feedback were correct, one would predict that the late prometamorphic and climax stages (i.e. stage 59 and 62 respectively) would be most sensitive to $\mathrm{TH}$ negative feedback, particularly for $\mathrm{T}_{4}$. We observed the opposite trend in our pituitary explant culture studies, with stage 56 pituitaries being more sensitive to $T_{3}$ and, perhaps more importantly, to $T_{4}$ than either stage 59 or 62 pituitaries (Figs 2 and 3). The downregulation of TSH expression by $\mathrm{T}_{4}$ suggests that DII is either active in the pituitary throughout prometamorphosis, or the conversion of $T_{4}$ to $T_{3}$ via DII is not required for negative feedback. Our pituitary developmental gene expression analysis shows that DII mRNA is present at stage 52 , increases steadily to peak levels at stage 59 and remains elevated through stage 64 (Fig. 5). At first glance it would appear 
that our data differ from those reported by Huang and colleagues (2001), i.e. that DII is only expressed at metamorphic climax. However, they examined DII expression only at stages 56 and 62 (and sample sizes were not reported), and they used the less sensitive method of Northern blotting. Our data indicate that, like several other genes in the pituitary, the expression of both DII and DIII increase in parallel with TH levels and TSH expression throughout metamorphosis (Fig. 5). Deiodinases likely play an important role in the regulation of intrapituitary TH concentrations, with DII and DIII working in concert to ensure appropriate TH levels. However, our data do not support the hypothesis that either gene plays a dominant role in sustaining the rise in thyroidal activity during metamorphosis, or that the expression of DII 'switches on' negative feedback at metamorphic climax.

To further address whether negative feedback is somehow activated at climax, we reevaluated the expression of pituitary TSH during X. laevis metamorphosis. In contrast to the data reported by Buckbinder and Brown (1993), we did not observe a sharp decline in TSH expression at metamorphic climax (Fig. 4). These data further argue against an abrupt onset of negative feedback at metamorphic climax. Okada and colleagues (2000) also failed to detect a sharp decline in TSH expression immediately after metamorphic climax in $R$. catesbeiana. In their study, a decline in TSH expression was not observed until Taylor-Kollros stage XXIV, which is equivalent to NF stage 65 in X. laevis development, and is the final stage of metamorphosis. Consistent with our finding that TSH expression does not decline until after stage 64, we also found that whole body $\mathrm{T}_{4}$ content does not decline until metamorphosis is completed at stage 66 (Krain \& Denver 2004).

Taken together, the findings of our study and those of others show that negative feedback is active throughout metamorphosis and there is no abrupt change in either the negative feedback response or deiodinase mRNA expression in the pituitary gland at metamorphic climax. If the lack of TH negative feedback on pituitary TSH is not responsible for facilitating the sustained rise in thyroidal activity during prometamorphosis then what mechanisms might underlie the development of the high level of thyroidal activity necessary for the completion of metamorphosis? One mechanism, first proposed by Etkin and colleagues (Etkin et al. 1965, Etkin 1966) involves the maturation of hypothalamic neurosecretory nuclei and the median eminence, where neurohormones are delivered to the pituitary portal circulation. This hypothesis is supported by both morphological and gene expression data (Etkin et al. 1965, Etkin 1966, Denver 1996). It is also possible that the sensitivity of the pituitary gland to neurohormonal stimulation develops during prometamorphosis in parallel with the development of the hypothalamus and median eminence. Such maturation of the neuroendocrine system would result in the increased drive for TSH production.

It is well established that an intact hypothalamus and pituitary are required for metamorphosis. Metamorphic climax can be prevented by ablation of the hypothalamic primordia, ecotopic transplantation of the pituitary gland or disruption of the hypothalamic-pituitary portal system by physical barriers (reviewed by Denver 1996). In mammals and other higher vertebrates, TRH is the primary regulator of TSH synthesis and secretion, and thus of the thyroid axis. In amphibians, TRH does not regulate thyroid secretion in larvae, but it can stimulate TSH secretion in adults (see Denver 1996, Okada et al. 2004). There is now considerable evidence that shows that CRF functions as a larval amphibian TSH releasing factor (reviewed by Denver et al. 2002). Okada and colleagues (2004) recently demonstrated, using an homologous TSH radioimmunoassay, that TRH has no effect, but CRF is a potent secretagog for TSH on pituitaries derived from bullfrog tadpoles. Furthermore, CRF-like peptides can modulate amphibian metamorphosis through the stimulation of both the thyroid and interrenal axes (reviewed by Denver et al. 2002). Our studies show that the expression of the mRNAs for the CRF receptors $\left(\mathrm{CRF}_{1}\right.$ and $\left.\mathrm{CRF}_{2}\right)$ increased in the tadpole pituitary throughout prometamorphosis, with a peak at stage 59 , and continued expression at this peak level through stage 64 (Fig. 6). This finding suggests that the sensitivity of the tadpole pituitary to CRF increases during metamorphosis. Recently, De Groef and colleagues (2003) showed that $\mathrm{CRF}_{2}$ expression is localized to the thyrotropes in the chick pituitary, while $\mathrm{CRF}_{1}$ is expressed only in corticotropes. The secretion of TSH by the chick pituitary gland is stimulated by CRF, and De Groef and colleagues (2003) provided pharmacological evidence that this stimulation is mediated by $\mathrm{CRF}_{2}$. We hypothesize that a similar expression pattern of CRF receptors exists in the tadpole pituitary, although we have not yet tested this.

For TRH, while the levels of TRH-R1 mRNA were relatively constant, we observed a strong increase in pituitary TRH-R2 mRNA during prometamorphosis. Three putative TRH receptors have been cloned in $X$. laevis (Bidaud et al. 2002). Recently, Lu and colleagues (2003) found that the TRH-R1 exhibits high affinity for TRH and TRH analogs similar to the mouse TRH-R1. By contrast, the frog TRH-R2 exhibited lower affinity for TRH analogs, but the hierarchy of binding was similar to the mammalian TRH receptors ( $\mathrm{Lu}$ et al. 2003). Interestingly, the receptor designated TRH-R3 exhibited very low affinities for all TRH analogs tested, which led the authors to conclude that the putative $X$. laevis TRH-R3 is a receptor for another peptide ligand ( $\mathrm{Lu}$ et al. 2003). Galas and colleagues (2003) found, using in situ hybridization histochemistry, that while TRH-R1 and TRH-R2 mRNAs are expressed in the $X$. laevis pars distalis, the 'TRH-R3' mRNA is only expressed in the pars 
intermedia. We did not analyze the expression of this 'TRH-R3' gene in our study. The increased expression of TRH-R2 in the tadpole pituitary gland during metamorphosis suggests the possibility that the gland increases its sensitivity to TRH at this time. While TRH does not affect tadpole TSH secretion, it has been hypothesized that TRH could contribute to the rise in pituitary prolactin production that occurs during late prometamorphosis (White \& Nicoll 1981, Norris 1989, Buckbinder \& Brown 1993).

Interestingly, we discovered that mRNAs for both CRF and TRH were expressed in the tadpole pituitary gland throughout metamorphosis (Figs 6 and 7), suggesting a possible autocrine or paracrine role for these neuropeptides. Paracrine and autocrine regulation of pituitary TSH and corticotropin (ACTH) by the intrapituitary expression of neuropeptides has been reported in humans and rats (Pagesy et al. 1992, Bruhn et al. 1998, Giraldi \& Cavagnini 1998). TRH mRNA was localized to rat pituitary somatotropes (Bruhn 1994a,b,c) and TRH of pituitary origin can modulate both the secretion of TSH and the biosynthesis of pituitary TRH respectively (Bruhn et al. 1998). Similarly, CRF mRNA was localized to the corticotropes in the rat pituitary (Thompson 1987, Giraldi \& Cavagnini 1998) and there is evidence for the regulation of ACTH secretion by CRF of pituitary origin (Giraldi \& Cavagnini 1998).

In summary, our data clearly show that negative feedback at the level of the pituitary is active from early prometamorphosis in X. laevis, and that both $\mathrm{T}_{4}$ and $\mathrm{T}_{3}$ can suppress pituitary TSH mRNA expression throughout metamorphosis. We found that the components necessary for the pituitary gland to respond to neurohormones are expressed at the highest levels during the peak phase of thyroidal activity. Taken together with the observation that the hypothalamic neurosecretory neurons and the median eminence, the structure necessary for the delivery of neurohormone to the pituitary, develop during prometamorphosis under the influence of $\mathrm{TH}$, our data support the hypothalamic drive hypothesis for the sustained production of TSH during amphibian metamorphosis.

\section{Acknowledgements}

We are grateful to Donald D Brown for providing the cDNAs for $X$. laevis TSH $\beta$ and $\alpha-G S U$. Yun-Bo Shi kindly provided the cDNA for $X$. laevis rpL8.

\section{Funding}

This work was supported by NSF grants IBN 9974672 and IBN 0235401 to R J D. R G M was supported by a postdoctoral fellowship from the Natural Sciences and Engineering Research Council of Canada (NSERC).

\section{References}

Becker KB, Stephens KC, Davey JC, Schneider MJ \& Galton VA 1997 The type 2 and type 3 iodothyronine deiodinases play important roles in coordinating development in Rana catesbeiana tadpoles. Endocrinology 138 2989-2997.

Bidaud I, Lory P, Nicolas P, Bulant M \& Ladram A 2002 Characterization and functional expression of cDNAs encoding thyrotropin-releasing hormone receptor from Xenopus laevis-identification of a novel subtype of thyrotropin-releasing hormone receptor. European Journal of Biochemistry 269 4566-4576.

Bruhn TO, Bolduc TG, Rondeel JMM \& Jackson IMD 1994a TRH gene expression in the anterior pituitary. II. Stimulation by glucocorticoids. Endocrinology 134 821-825.

Bruhn TO, Rondeel JMM, Bolduc TG \& Jackson IMD $1994 b$ TRH gene expression in the anterior pituitary. I. Presence of pro-TRH mRNA and pro-TRH-derived peptides in a subpopulation of somatotrophs. Endocrinology 134 815-820.

Bruhn TO, Rondeel JMM, Bolduc TG \& Jackson IMD 1994c TRH gene expression in the anterior pituitary. III. Stimulation by thyroid hormone: potentiation by glucocorticoids. Endocrinology 134 826-830.

Bruhn TO, Rondeel JMM \& Jackson IMD 1998 Thyrotropin-releasing hormone gene expression in the anterior pituitary. IV. Evidence for paracrine and autocrine regulation. Endocrinology 139 3416-3422.

Buckbinder L \& Brown DD 1993 Expression of the Xenopus laevis prolactin and thyrotropin genes during metamorphosis. PNAS $\mathbf{9 0}$ 3820-3824.

Cohen RN, Weintraub BD \& Wondisford FE 2000 Factors that control thyroid function: thyrotropin. In Werner \& Ingbar's The Thyroid: A Fundamental and Clinical Text, edn 8, pp. 202-219. Eds LE Braverman \& RD Utiger. Philadelphia: Lippincott Williams \& Wilkins.

De Groef B, Goris N, Arckens L, Kuhn ER \& Darras VM 2003 Corticotropin-releasing hormone $(\mathrm{CRH})$-induced thyrotropin release is directly mediated through $\mathrm{CRH}$ receptor type 2 on thyrotropes. Endocrinology 144 5537-5544.

Denver RJ 1988 Several hypothalamic peptides stimulate in vitro thyrotropin secretion by pituitaries of anuran amphibians. General and Comparative Endocrinology 72 383-393.

Denver RJ 1996 Neuroendocrine control of amphibian metamorphosis. In Metamorphosis: Postembryonic Reprogramming of Gene Expression in Amphibian and Insect Cells, edn 3, pp 433-464. Eds LI Gilbert, JR Tata \& BG Atkinson. San Diego: Academic Press.

Denver RJ, Pavgi S \& Shi YB 1997 Thyroid hormone-dependent gene expression program for Xenopus neural development. Journal of Biological Chemistry 272 8179-8188.

Denver RJ, Boorse GC \& Glennemeier KA 2002 Endocrinology of complex life cycles: amphibians. In Hormones, Brain and Behavior, vol. 2, pp 469-513. Eds D Pfaff, A Arnold, A Etgen, S Fahrbach, R Moss \& R Rubin. San Diego: Academic Press.

Dodd MHI \& Dodd JM 1976 The biology of metamorphosis. In Physiology of the Amphibia, vol. 3, pp 467-599. Ed. B Lofts. New York: Academic Press.

Eddy L \& Lipner H 1976 Amphibian metamorphosis: role of thyrotropin-like hormone. General and Comparative Endocrinology 29 333-336.

Etkin W 1966 Hypothalamic sensitivity to thyroid feedback in the tadpole. Neuroendocrinology 1 293-303.

Etkin W 1968 Hormonal control of amphibian metamorphosis. In Metamorphosis: A Problem in Developmental Biology, edn. 1, pp 313-348. Eds W Etkin \& LI Gilbert. New York: Appleton-Century-Crofts.

Etkin W, Kikuyama S \& Rosenbluth J 1965 Thyroid feedback to the hypothalamic neurosecretory system in frog larvae.

Neuroendocrinology 1 45-64. 
Galas L, Bidaud I, Bulant M, Jenks BG, Ouwens DTWM, Jegou S, Ali L, Roubos EW, Tonon M-C, Nicolas P \& Vaudry H 2003 Comparative distribution of the mRNAs encoding the three thyrotropin-releasing hormone (TRH) receptors in the brain and pituitary of Xenopus laevis. Effect of background color adapation on TRH receptor gene expression. Proceedings of the International Symposium on Amphibian and Reptilian Endocrinology and Neurobiology, Jeju National University, Seogwipo, Korea. pp 15.

Giraldi FP \& Cavagnini F 1998 Corticotropin-releasing hormone is produced by rat corticotropes and modulates ACTH secretion in a paracrine/autocrine fashion. Journal of Clinical Investigation 101 $2478-2484$

Goos HJT 1978 Hypophysiotropic centers in the brain of amphibians and fish. American Zoologist 18 401-410.

Goos HJT, De Knecht AM \& De Vries J 1968a Hypothalamic neurosecretion and metamorphosis in Xenopus laevis. I. The effect of propylthiouracil. Zeitschrift fur Zellforschung und Mikroskopische Anatomie 86 384-392.

Goos HJT, Zwanebeek HCM \& van Oordt PGWJ $1968 b$ Hypothalamic neurosecretion and metamorphosis. II. The effect of thyroxine following treatment with propylthiouracil. Archives d'Anatomie, d'Histologie, et d'Embryologie Normales et Experimentales 51 267-274.

Hanoaka Y 1967 Effect of phenylthiourea upon posterior hypothalectomized tadpoles of Rana pipiens. General and Comparative Endocrinology 9 24-30.

Huang H, Cai L, Remo BF \& Brown DD 2001 Timing of metamorphosis and the onset of the negative feedback loop between the thyroid gland and the pituitary is controlled by type II iodothyronine deiodinase in Xenopus laevis. PNAS $\mathbf{9 8}$ $7348-7353$.

Huang Z, Fasco MJ \& Kaminsky LS 1996 Optimization of DNase I removal of contaminating DNA from RNA for use in quantitative RNA-PCR. BioTechniques 20 1012-1020.

Jacobs GF \& Kuhn ER 1992 Thyroid hormone feedback regulation of the secretion of bioactive thyrotropin in the frog. General and Comparative Endocrinology 88 415-423.

Kawahara A, Gohda Y \& Hikosaka A 1999 Role of type III iodothyronine 5-deiodinase gene expression in temporal regulation of Xenopus metamorphosis. Development Growth and Differentiation 41 365-373.

Kaye NW 1961 Interrelationships of the thyroid and pituitary in embryonic and premetamorphic stages of the frog Rana pipiens. General and Comparative Endocrinology 64 129-135.

Kikuyama S, Kawamura K, Tanaka S \& Yamamoto K 1993 Aspects of amphibian metamorphosis: hormonal control. International Review of Cytology 145 105-148.

Krain LP \& Denver RJ 2004 Developmental expression and hormonal regulation of glucocorticoid and thyroid hormone receptors during metamorphosis in Xenopus laevis. Journal of Endocrinology 181 91-104.

Kurabuchi A, Tanaka S \& Kikuyama S 1992 Development of TSH cells in larval toad, Bufo japonicus during metamorphosis and their response to thyroxine and thiourea. Proceedings of the International Symposium on Amphibian Endocrinology, Waseda University, pp. 26.

Leloup J \& Buscaglia M 1977 La triiodothyronine: hormone de la métamorphose des amphibians. Comptes Rendus de l'Academie des Sciences 284 2261-2263.
Licht P \& Denver RJ 1990 Regulation of pituitary thyrotropin secretion. Progress in Clinical and Biological Research 342 427-432.

Lu XP, Bidaud I, Ladram A \& Gershengorn MC 2003 Pharmacological studies of thyrotropin-releasing hormone (TRH) receptors from Xenopus laevis: Is XTRHR 3 a TRH receptor? Endocrinology 144 1842-1846.

MacKenzie DS \& Licht P 1978 Thyrotropin from amphibian (Rana catesbeiana) pituitaries and evidence for heterothyrotropic activity of bullfrog luteinizing hormone in reptiles. General and Comparative Endocrinology 36 566-574.

Nieuwkoop PD \& Faber J 1956 Normal Table of Xenopus laevis (Daudin): a Systematical and Chronological Survey of the Development from the Fertilized Egg til the End of Metamorphosis. Amsterdam: North Holland Publishing Co.

Norris DO 1989 Neuroendocrine aspects of amphibian metamorphosis. In Development, Maturation and Senescence of Neuroendocrine System: a Comparative Approach, pp 63-90. Eds CG Scanes \& MP Schreibman. San Diego: Academic Press.

Okada R, Iwata T, Kato T, Kikuchi M, Yamamoto K \& Kikuyama S 2000 Cloning of bullfrog thyroid-stimulating hormone (TSH) $\beta$ subunit cDNA: expression of TSH $\beta$ mRNA during metamorphosis. General and Comparative Endocrinology 119 224-231.

Okada R, Yamamoto K, Koda A, Ito Y, Hayashi H, Tanaka S, Hanaoka Y \& Kikuyama S 2004 Development of radioimmunoassay for bullfrog thyroid-stimulating hormone (TSH): effects of hypothalamic releasing hormones on the release of TSH from the pituitary in vitro. General and Comparative Endocrinology 135 42-50.

Pagesy P, Croissandeau G, Le Dafniet M, Peillon F \& Li JY 1992 Detection of thyrotropin-releasing hormone (TRH) mRNA by the reverse transcription-polymerase chain reaction in the human normal and tumoral anterior pituitary. Biochemical and Biophysical Research Communications 182 182-187.

Shi YB 2000 Amphibian Metamorphosis: From Morphology to Molecular Biology. New York: Wiley-Liss.

Shi YB \& Liang VC 1994 Cloning and characterization of the ribosomal protein L8 gene from Xenopus laevis. Biochimica et Biophysica Acta 1217 227-228.

Shupnik MA, Chin WW, Habener JF \& Ridgway EC 1985 Transcriptional regulation of the thyrotropin subunit genes by thyroid hormone. Journal of Biological Chemistry 260 2900-2903.

Sokal RR \& Rohlf FJ 1981 Biometry. New York: WH Freeman and Company.

Thompson RC, Seasholtz AF \& Herber E 1987 Rat corticotropin-releasing hormone gene: sequence and tissue-specific expression. Molecular Endocrinology $1363-370$.

Ury HK 1976 A comparison of four procedures for multiple comparisons among means (Pairwise Contrasts) for arbitrary sample sizes. Technometrics 18 89-97.

White BA \& Nicoll CS 1981 Hormonal control of amphibian metamorphosis. In Metamorphosis: a Problem in Developmental Biology, edn 2, pp 363-396. Eds LI Gilbert \& E Frieden. New York: Plenum.

Received in final form 24 May 2004

Accepted 2 June 2004

Made available online as an

Accepted Preprint 8 June 2004 